\title{
ПРАВОВОЕ РЕГУЛИРОВАНИЕ ИЗМЕНЕНИЯ И РАСТОРЖЕНИЯ ДОГОВОРА АРЕНДЫ ЗЕМЕЛЬНОГО УЧАСТКА
}

Аннотация: Предметом исследования вопроса изменения и расторжения договора аренды земельного участка являются правоотношения, связанные с прекрашуением договорных арендных обязательств, где объектом выступает земельный участок. Данные правоотношения носят смешанный характер, так как регулируются гражданским, земельным и иным законодательством РФ. В статье поднимаются несколько дискуссионных аспектов расторжения договора аренды земельного участка: соотношение прекращения договора и прекращцение обязательств, проблема исполнение договора и последующее его расторжение, вопросы последствия расторжения договора аренды земельного участка. Методологическую основу настоящей работы составляют: общенаучные методы - анализ, синтез, сравнение, абстрагирование, классификация; специальные юридические методы аналогия, толкование, критический анализ, обзор правовых актов. Новизна данного исследования заключается в рассмотрении вопроса изменения и расторжения договора на примере договора аренды земельного участка. В работе автор рассматривает как расторжение договора по соглашению сторон, так и в одностороннем порядке. В результате исследования автор предлагает внести изменения в действуюшее законодательство РФ.

Ключевые слова: Правоотношения, обязательство, прекращение, договор, расторжение, изменение, земля, аренда, регистрация, основания.

Abstract: The subject of this research is the legal relations pertaining to the changes and termination of the land lease agreements associated with the discontinuation of lease obligations, where the object is a piece of land. These legal relations carry a mixed character, as they are regulated by the civil, land, and other legislation of the Russian Federation. The article presents a few debatable aspects of termination of a land lease agreement: correlation between termination of the agreement and discontinuation of obligations; the questions of consequences of termination of a land lease agreement. The author examines termination of a lease based on a mutual agreement, as well as by a unilateral decision. In conclusion the author proposes making changes to the current legislation of the Russian Federation.

Keywords: Lease, land, amendment, termination, contract, discontinuation, obligation, legal relation, registration, basis.

азой правового регулирования изменения и расторжения договора аренды земельного участка служат общие положения изменения и расторжения договора (глава 29 ГК РФ). При этом изменение и расторжение договора возможны по соглашению сторон, если иное не предусмотрено договором или законом. В одностороннем порядке договор может быть расторгнут или изменен только по решению суда. Исключением из этого правила являются договоры аренды земельного участка, заключенные до 1 января 2011 года для целей строительства, реконструкции объекта недвижимого имущества договор аренды земельного участка, находящегося в государственной или муниципальной собственности и расположенного в границах субъекта Российской Федерации - города федерального значения Москвы или Санкт-Петербурга. В этом случае закон [2] позволяет арендодателю расторгнуть договор в одностороннем порядке в течение одного месяца с момента направления им уведомления арендатору.
По данному положению правильно высказывается О.М. Козырь: «возможности арендодателя расторгнуть в одностороннем порядке договоры долгосрочной аренды земельных участков из государственных или муниципальных земель были в значительной мере ограничены после принятия Земельного кодекса Российской Федерации 2001 г. для обеспечения стабильности прав на землю и создания благоприятных условий для инвестирования. Но введенное недавно федеральным законодательством одностороннее расторжение долгосрочных договоров аренды земельных участков из государственных или муниципальных земель в городах Москве и Санкт-Петербурге по инициативе арендодателя, по сути, стало еще одним способом принудительного прекращения прав на землю во внесудебном порядке» $[13,35]$.

Другим исключением из этого правила является норма, позволяющая расторгнуть договор аренды, заключенный на неопределенный срок, в одностороннем порядке. При этом договор может быть расторгнуть лю- 


\section{Право и политика 4 (184) 2015}

бой из сторон, в любое время и всего лишь достаточно предупредить об этом другую сторону за три месяца. Такая норма, как утверждает Г. Иванов-Лебедев [11,44], распространяет свое действие на частные земельные участки, а также земельные участки, находящиеся в государственной и муниципальной собственности, срок аренды фактически которых уже составил 5 лет к моменту расторжения договора.

Одним из оснований для расторжения договора является существенное нарушение договора другой стороной. Однако, как правильно указали Д.В. Литвинова и Т.В. Филина, «закон не содержит никаких положений о том, что арендодатель должен доказать не только наличие нарушений со стороны арендатора, но и существенность таких нарушений. На наличие этой обязанности указывается судами. Так, согласно Постановлению Федерального арбитражного суда Московского округа от 22 апреля 2013 года по делу № A40-95609/11-150-785 особый порядок расторжения договора аренды земельного участка предусматривает обязанность арендодателя представить суду доказательства, подтверждающие существенное нарушение арендатором условий договора аренды. Такие доказательства принимаются с учетом следующих обстоятельств:

- имело ли место нарушение со стороны арендатора, является ли оно существенным для арендодателя в смысле общего гражданского понятия «существенное нарушение»;

- имели ли место обстоятельства, препятствующие исполнению арендатором обязательств и использованию им участка в установленных договором целях» $[14,4]$.

В своем Постановлении Пленум ВАС РФ указал, что пункт 2 статьи 610 ГК РФ предусматривает право каждой из сторон договора аренды, заключенного на неопределенный срок, немотивированно отказаться от договора, предупредив об этом другую сторону в названные в данной норме сроки. Эта норма хотя и не содержит явно выраженного запрета на установление иного соглашением сторон, но из существа законодательного регулирования договора аренды как договора о передаче имущества во временное владение и пользование или во временное пользование (статья 606 ГК РФ) следует, что стороны такого договора аренды не могут полностью исключить право на отказ от договора, так как в результате этого передача имущества во владение и пользование фактически утратила бы временный характер [5].

Как правильно отметила М.А. Егорова, стороны вправе самостоятельно избирать способ изменения и расторжения договора. Альтернатива, предоставляемая управомоченной стороне договора, связанная с избранием порядка изменения и расторжения договора, базируется на принципе диспозитивности и основных начал гражданско-правового метода регулирования общественных отношений $[8,276]$.

Важно отметить, что п. 2 Постановления Пленума ВАС РФ от 06.06.2014 г. № 35 «О последствиях расторжения договора» [3] устанавливает следующее: последствия расторжения договора, отличающиеся от тех, которые установлены в статье 453 ГК РФ, могут содержаться в положениях об отдельных видах договоров. Правила статьи 453 Кодекса в указанных случаях применяются в той мере, в какой они не противоречат положениям специальных норм. Последствия расторжения договора, отличные от предусмотренных законом, могут быть установлены соглашением сторон с соблюдением общих ограничений свободы договора, определенных в постановлении Пленума Высшего Арбитражного Суда Российской Федерации от 14.03.2014 № 16 «О свободе договора и ее пределах».

Основания для досрочного расторжения договора по требованию одной из сторон договора аренды перечислены в ст.ст. 619, 620 ГК РФ. Причем этот перечень носит ограниченный характер. Однако не все указанные случаи распространяются на договор аренды земельного участка, например, если не производится капитальный ремонт имущества, переданного в аренду. Одним из оснований также является не предоставление имущества (земельного участка) в пользование арендатору, при этом доказать факт передачи или не передачи не представляется возможным, ввиду отсутствия законодательного требования к моменту передачи имущества. В связи с этим предлагается в ЗК РФ включить норму «Передача земельного участка»

1. Передача земельного участка и принятие его арендатором производится по передаточному акту или иному документу, подписываемому сторонами.

2. При прекращении договора аренды земельный участок должен быть возвращен арендодателю с соблюдением правил, предусмотренных п.1 настоящей статьи.

Важно отметить, что законодательство РФ предоставляет право досрочно расторгнуть договора аренды арендодателю только после направления арендатору письменного предупреждения о необходимости исполнения им обязательств в разумный срок.

«Функция предупреждения состоит в том, чтобы предоставить арендатору последнюю возможность исправить допущенное им нарушение: если он устранит 
нарушение до истечения установленного срока, то договор аренды не может быть расторгнут» [16,31].

Арендатору такого требования не предъявляется, что ставит стороны в неравное положение. Считаем, что данное требование нарушает принцип равенства участников, заложенный в основе гражданского законодательства РФ.

При этом ВАС РФ разъяснил, что судам следует учитывать, что даже после уплаты долга арендодатель вправе в разумный срок предъявить иск о расторжении договора. Однако не предъявление такого требования в течение разумного срока с момента уплаты арендатором названного долга лишает арендодателя права требовать расторжения договора в связи с этим нарушением [4].

Изменить или расторгнуть договор можно только в том случае, если он является действительным. Это отмечается и в судебной практике. Например, в Определении Верховного Суда РФ от 25.06.2013 № 18-КГ13-42.

Как указывает А.М. Эрделевский, довольно много сложностей вызывает правило п. 4 ст. 453 ГК, согласно которому стороны расторгнутого договора не вправе требовать возвращения того, что было исполнено ими по обязательству до момента расторжения договора, если иное не установлено законом или соглашением сторон [17]. При этом все полученное по сделки до расторжения договора не подлежит возвращению, если до момента расторжения договора обязательства исполнялись надлежащим образом. В этом случае досрочного расторжения договора ни одна из сторон не вправе требовать, так как все случаи досрочного расторжения договора арендатором или арендодателем, указанные в ГК РФ, относятся к неисполнению или ненадлежащему исполнению обязательств по договору.

Другим немаловажным проблемным аспектом данного вопроса является расторжение или изменение договора аренды земельных участков, заключенных на срок равный или более 1 года. Такой договор подлежит государственной регистрации и считается заключенным с момента такой регистрации. Таким образом, все изменения и тем более расторжение договора подлежат государственной регистрации, однако не ясно кто из сторон будет осуществлять данную регистрацию.

Последствием расторжения договора является прекращение обязательств (п. 2 ст. 452 ГК РФ). Однако следует ли под этим понимать само прекращение договора? Вопрос соотношения прекращения обязательств с прекращением договора является дискуссионным.

Так, Д.И. Мейер писал, что «прекращение сделки не всегда составляет ее последний акт, а бывает, что вследствие прекращения сделки участникам ее приходится совершить еще какие-либо действия, так что, несмотря на прекращение, сделка все-таки оказывает еще известное действие» [15].

Н.Ю. Шлюндт полагает, что «расторжение договора аренды - это волевое действие, инициируемое стороной (сторонами), имеющее своей целью прекратить существование содержания арендных обязательств, а следовательно, всей совокупности прав и обязанностей» [10].

По мнению М.А. Егоровой, расторжение договора нельзя рассматривать и в качестве гражданско-правового правоотношения, так как расторжение договора происходит автоматически в момент совершения сделки, являющейся последним элементом юридического состава, направленного на расторжение договора. Правовым результатом воздействия оснований расторжения договора на договорное правоотношение является полный разрыв всех существующих правовых связей, составляющих содержание такого правоотношения, т.е. происходит прекращение обязательства $[9,11]$.

Д.Б. Абушенко считает, что при вынесении судебного решения о расторжении договора конкретный момент, с которого договор считается расторгнутым, определяется соглашением сторон, которое может как содержаться в самом договоре, так и быть результатом самостоятельной сделки, совершенной сторонами в любой момент вплоть до вынесения судебного решения $[6,60]$.

«Исходя из положений статьи 453 ГК РФ при расторжении договора обязательства сторон прекращаются, и наоборот: при прекращении обязательств сторон происходит расторжение договора. Это значит, что прекращается не сам договор, а права и обязанности сторон, которые образуют его содержание, следствием чего является расторжение договора» $[12,35]$.

По нашему мнению, прекращение обязательств это всего лишь следствие прекращения договора. Прекращение обязательств ведет к прекращению договора, лишь в том случае, если договор аренды земельного участка не подлежал государственной регистрации согласно Федеральному закону от 21.07.1997 г. «О государственной регистрации прав на недвижимое имущество и сделок с ним» [1]. Если же договор зарегистрирован в установленном законом порядке стороны могут продолжать исполнение обязательств по договору до момента внесения регистрирующими органами в государственный реестр прав на недвижимое имущество и сделок с ним записи о прекращении договора. 


\section{Право и политика 4 (184) 2015}

\section{Библиография:}

1. Федеральный закон от 21.07.1997 № 122-ФЗ«О государственной регистрации прав на недвижимое имущество и сделок с ним» // «Российская газета», № 145, 30.07.1997.

2. Федеральный закон РФ от 25.10.2001 № 137-ФЗ «О введении в действие Земельного кодекса РФ» // Российская газета, №211-212, 30.01.2001.

3. Постановление Пленума ВАС РФ от 06.06.2014 г. № 35 «О последствиях расторжения договора» // Вестник ВАС РФ. №8, август, 2014.

4. Постановление Пленума ВАС РФ от 17.11.2011 г. №73 «Об отдельных вопросах практики применения правил ГК РФ о договоре аренды» // Вестник ВАС РФ, №1, январь, 2012.

5. Пленум ВАС РФ от 14.03.2014 г. №16 «О свободе договора и ее пределах» // Вестник ВАС РФ, №5, май, 2014.

6. Абушенко Д.Б. О материально-и процессуально-правовых особенностях исков и судебных решений по требованиям о заключении, изменении и прекращении договора // Вестник гражданского процесса. 2013. № 2. С. 60

7. Барановская И.Г.Договор аренды земельного участка как проблема науки российского гражданского права: монография.Ю-Сах.: Издательство ЮСИЭПИ, 2010. - 100с.

8. Егорова А.М. Основные направления совершенствования положений об изменении и расторжении договоров // Проблемы совершенствования гражданского законодательства: Материалы IV Ежегодных научных чтений памяти профессора С.Н. Братуся / Институт законодательства и сравнительного правоведения при Правительстве РФ. - М.: ИД «Юриспруденция», 2010. - С. 276.

9. Егорова М.А. Правовая природа расторжения договора // Юрист. 2013. № 17. С. 11.

10. Изменение и расторжение договора аренды. Дис. ... канд.юрид.наук: 12.00.03/ Шлюндт Н.Ю. Краснодар, 2005.

11. Иванов-Лебедев Г. Неопределенный срок-расторжение договора аренды земли через суд // Юрист. 2011. № 21. С. 44.

12. Кандауров А.В. Односторонний отказ от исполнения, прекращения и расторжения договора аренды // Законодательство и экономика. 2010. N 3. С. 35.

13. Козырь О.М. Одностороннее расторжение договора аренды земельного участка // Экологическое право. 2012. №5. С.34-37.

14. Литвинов Д.В., Филина Т.В. Защита прав арендаторов земельных участков при одностороннем расторжении договоров аренды в городе Москве // Имущественные отношения в Российской Федерации. 2013. №12. C.58-63.

15. Мейер Д.И. Русское гражданское право [Электронный ресурс]. - Режим доступа: http://civil.consultant.ru/elib/books/45/ page_1.html\#1

16. Никурадзе А.Ш. Изменение и расторжение договора аренды // Юрист. 2011. N 24. С. 31.

17. Эрделевский А.М. Последствия расторжения договора: судебная практика // СПС КонсультантПлюс. 2014.

\section{References (transliterated):}

1. Abushenko D.B. O material'no-i protsessual'no-pravovykh osobennostyakh iskov i sudebnykh reshenii po trebovaniyam o zaklyuchenii, izmenenii i prekrashchenii dogovora // Vestnik grazhdanskogo protsessa. 2013. № 2. S. 60

2. Baranovskaya I.G.Dogovor arendy zemel'nogo uchastka kak problema nauki rossiiskogo grazhdanskogo prava: monografiya.Yu-Sakh.: Izdatel'stvo YuSIEPI, 2010. - 100s.

3. Egorova A.M. Osnovnye napravleniya sovershenstvovaniya polozhenii ob izmenenii i rastorzhenii dogovorov // Problemy sovershenstvovaniya grazhdanskogo zakonodatel'stva: Materialy IV Ezhegodnykh nauchnykh chtenii pamyati professora S.N. Bratusya / Institut zakonodatel'stva i sravnitel'nogo pravovedeniya pri Pravitel'stve RF. - M.: ID «Yuricprudentsiya», 2010. - S. 276.

4. Egorova M.A. Pravovaya priroda rastorzheniya dogovora // Yurist. 2013. № 17. S. 11.

5. Ivanov-Lebedev G. Neopredelennyi srok-rastorzhenie dogovora arendy zemli cherez sud // Yurist. 2011. № 21. S. 44.

6. Kandaurov A.V. Odnostoronnii otkaz ot ispolneniya, prekrashcheniya i rastorzheniya dogovora arendy // Zakonodatel'stvo i ekonomika. 2010. N 3. S. 35.

7. Kozyr' O.M. Odnostoronnee rastorzhenie dogovora arendy zemel'nogo uchastka // Ekologicheskoe pravo. 2012. №5. S.34-37.

8. Litvinov D.V., Filina T.V. Zashchita prav arendatorov zemel'nykh uchastkov pri odnostoronnem rastorzhenii dogovorov arendy $\mathrm{v}$ gorode Moskve // Imushchestvennye otnosheniya v Rossiiskoi Federatsii. 2013. №12. S.58-63.

9. Meier D.I. Russkoe grazhdanskoe pravo [Elektronnyi resurs]. - Rezhim dostupa: http://civil.consultant.ru/elib/books/45/page_1. html\#1

10. Nikuradze A.Sh. Izmenenie i rastorzhenie dogovora arendy // Yurist. 2011. N 24. S. 31.

11. Erdelevskii A.M. Posledstviya rastorzheniya dogovora: sudebnaya praktika // SPS Konsul'tantPlyus. 2014. 